\title{
LA CONSTRUCCIÓN DEL HOMBRE NUEVO: DE LA REVOLUCIÓN DE OCTUBRE AL POST-COMUNISMO. UNA PERSPECTIVA HISTÓRICA ${ }^{1}$
}

\author{
Àngel Ferrero \\ Universitat Autònoma de Barcelona
}

Resumen: El objetivo de este artículo es establecer el trasfondo histórico de la figura del hombre nuevo del socialismo desde sus comienzos en los círculos vanguardistas de 1917 tras la Revolución de Octubre -especialmente en la técnica de typage de Vsevolod Meyerhold, una importante influencia en Serguéi M. Eisenstein- hasta su simplificación durante el estalinismo y su adopción por parte de la República Popular China. Las imágenes icónicas y extremadamente codificadas del hombre nuevo del socialismo son analizadas aquí bajo una nueva luz, desafiando la imagen tradicional entre académicos del socialismo realista como un estilo artístico osificado, monolítico y carente de interés. La última parte del artículo trata de la desaparición del socialismo realista durante los ochenta con la desintegración de la URSS y la evolución de China a la llamada "economía de mercado socialista con características chinas", pero que aún persiste en Corea del Norte, que lo exporta a países africanos como Senegal o Namibia.

Palabras clave: Historia del arte, Realismo socialista, URSS, Rusia, China

\section{The Construction of the New Man: From The October Revolution to The Post-Communist Era: A Historical Perspective}

Abstract: The purpose of this paper is to draw the historical background of the figure of the Socialist New Man from his beginning in the Russian avant-garde circles of 1917 after the October Revolution -specially in Vsevolod Meyerhold's typage's technique, a major influence in Sergei M. Eisenstein- to its oversimplification as official aesthetic in Stalin's regime and its adoption by the People's Republic of China. The iconic and extremely codified images of the Socialist New Man are analyzed under a new light defying the traditional image among scholars of Socialist Realism as an ossified, monolithic and lackluster artistic style. The last part of the paper deals with the fading away of the Socialist Realism during the $80 \mathrm{~s}$ as the Soviet bloc disintegrated and China evolved into a so called "socialist market economy with Chinese characteristics", but persisted, applied adamantly, in North Korea, who exports it to African countries like Senegal or Namibia.

Keywords: Art history, Socialist Realism, USSR, Russia, China

\footnotetext{
${ }^{1}$ Este artículo desarrolla una ponencia realizada en la AAS/ICAS Joint Conference en Honolulu (Hawai'i, Estados Unidos), el 1 de abril de 2011. Quisiera agradecer a a Ellen Xiang $\mathrm{He}$ (Universidad de Nueva York) por su invitación y a Saúl Roas Deus (Universitat Autónoma de Barcelona), Pablo Carbajosa y Julie Wark por su colaboración.
} 


\section{En la devastación \\ borrando lo viejo, difundiremos un nuevo mito en el mundo.}

Vladimir Mayakovski (1922)

«¡Describir al Homosos [homo sovieticus]! ¡Qué desafío! En muchas décadas y puede que incluso dentro de siglos las personas que hayan resuelto este problema serán vistas como académicos excepcionales", escribía Alexander Zinóviev (1986: 257) en Homo sovieticus, una de sus novelas satíricas más conocidas. Hoy, sin embargo, todo son problemas: la expresión "hombre nuevo" no puede sonar más que extemporánea y pasada de moda tras el desplome del "socialismo real" y la transformación de los regímenes comunistas supervivientes -bien por la voluntad o el interés de sus dirigentes, bien forzados a la contemporización por la correlación internacional de fuerzasa formas sociales, económicas y políticas que no pueden denominarse en propiedad socialismo (ya se compare con el socialismo real o con formas de socialismo democrático), pero tampoco capitalismo. Es por ello que, con más razón si cabe, titular el ensayo "La construcción del hombre nuevo: de la Revolución de Octubre al post-comunismo. Una perspectiva histórica" acaso pueda resultar demasiado ambicioso, al intentar abarcar un período histórico de casi un siglo. Mi intención es, no obstante, bastante más modesta, por lo que me gustaría subrayar la última parte del título: "una perspectiva histórica". Con ello, intentaré ofrecer una visión de la evolución del concepto de "hombre nuevo" en la tradición socialista.

\section{Conceptualizando al hombre nuevo}

¿Qué significa "hombre nuevo" en la tradición socialista marxista de la que la República Popular China se reclama heredera? Si bien es cierto que todos los movimientos emancipatorios que han perseguido la abolición de la sociedad de clases han hablado de "un hombre nuevo" en unos términos u otros -el monje dominico Girolamo Savonarola, por ejemplo, habló de que su República Democrática de Florencia se transformaría en un «ciudad celestial» donde «los adultos vivirán de forma jubilosa» y «niños y niñas serán como ángeles» (en 
Fernández Buey, 2007: 70)- no encontramos en toda la obra de Marx y Engels ninguna caracterización del mismo. Así, a propósito del patriarcado -pero el juicio es cabalmente extensible a todo lo demás-, Engels escribió que todo lo que se podía conjeturar "después de la inminente supresión de la producción capitalista es, más que nada, de un orden negativo, y queda limitado, principalmente, a lo que debe desaparecer. Pero, ¿qué sobrevendrá? Eso se verá cuando haya crecido una nueva generación [...] $Y$ cuando esas generaciones aparezcan, enviarán al cuerno todo lo que nosotros pensamos que deberían hacer. Se dictarán a sí mismas su propia conducta, y, en consonancia, crearán una opinión pública para juzgar la conducta de cada uno. ¡Y todo quedará hecho!» (Engels [1884], 1998: 147-148) Encontrar lo contrario hubiera sido al fin y al cabo lo realmente sorprendente, pues esta cuestión limita con el socialismo utópico repetidamente denunciado en su obra, que es, ante todo y por decirlo con Korsch, fundamentalmente crítica. Fueron los bolcheviques, como primeros marxistas revolucionarios que habíanse de enfrentar a la construcción de una sociedad postcapitalista, quienes desarrollaron el concepto en un sentido más o menos marxista. En este sentido, el concepto de "hombre nuevo" es una invención propagandística de los bolcheviques, como lo fueron los de "democracia burguesa" (un oxímoron que no se encuentra en la obra de Marx, para quien los comunistas eran un ala de la democracia) o "materialismo dialéctico" (o su acrónimo, Diamat). El de "hombre nuevo" se enfrentaba incluso a la interpretación de Lenin, quien en El izquierdismo, enfermedad infantil del comunismo advertía -no sin ciertas dosis de utopismo- de las dificultades en la construcción del socialismo:

«El capitalismo lega inevitablemente al socialismo, de una parte, las viejas diferencias de profesión y de oficio entre los obreros, formadas en el transcurso de los siglos, y, de otra, los sindicatos, que sólo con gran lentitud, a lo largo de años y años, pueden transformarse y se transformarán en sindicatos de industria más amplios, menos corporativos (que engloben a industrias enteras y no sólo a corporaciones, oficios y profesiones). Después, a través de estos sindicatos de industria, se pasará a suprimir la división del trabajo entre los individuos; a educar, instruir y formar hombres universalmente desarrollados y universalmente preparados, hombres que sabrán hacerlo todo. Hacia eso marcha, debe marchar y llegará el comunismo, pero sólo dentro de muchos años. Intentar hoy anticiparse en la práctica a ese resultado futuro de un comunismo llegado a la plenitud de su desarrollo, solidez y formación, de su íntegra realización y de su madurez, es lo mismo que querer enseñar matemáticas superiores a un niño de cuatro años.

«Podemos (y debemos) emprender la edificación del socialismo no con un material humano fantástico ni especialmente creado por nosotros, sino con el que nos ha dejado como herencia el capitalismo. Esto es, sin duda, muy "difícil"; pero cualquier otro modo de enfocar el problema es tan poco serio que no merece la pena hablar de ello.» (Lenin [1920] 2001: 65-66)

Contrariamente a lo que se cree hoy, la opinión de Lenin no se imponía de manera autoritaria, y muchos bolcheviques tenían sus propias ideas al respecto. Después de la revolución de Octubre de 1917 y de la guerra civil, escribe Boris Groys (2008: 56-57), el país «se vio completamente devastado: el modo de vida normal, totalmente destruido; las viviendas, inservibles para la 
vida; la economía pasó casi a un estadio primitivo, los vínculos sociales tradicionales se desintegraron, y la vida fue adquiriendo gradualmente los rasgos de una guerra de todos contra todos. [...] Parecía que el tiempo del Apocalipsis había sobrevenido, y todas las cosas, desplazadas de sus puestos, se revelaron a la mirada apocalíptica de cada cual.»²

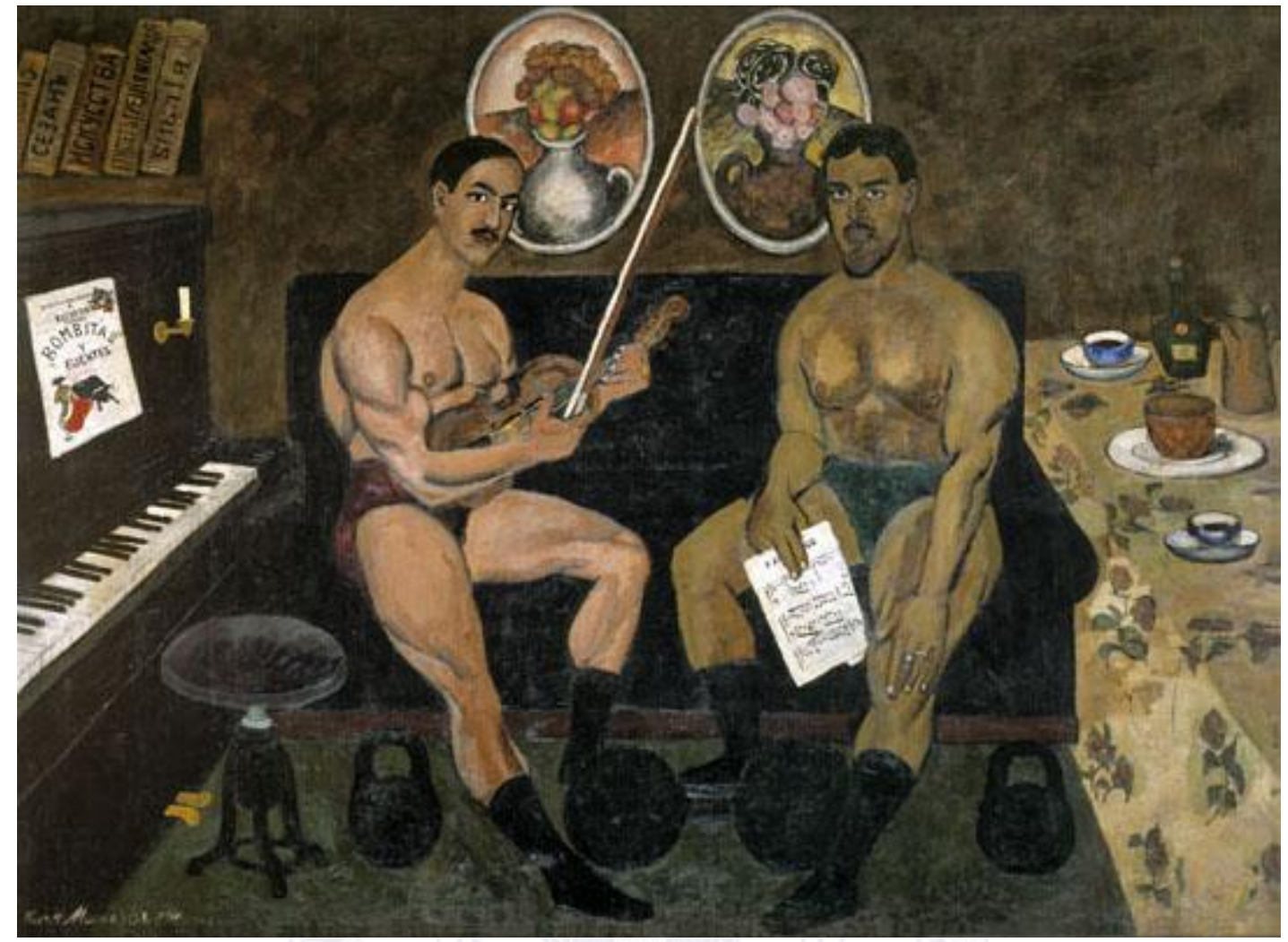

Autorretrato con Petr Konchalovsky (Ilia Mashkov, 1910)

En la conceptualización del hombre nuevo a partir de este "pensamiento apocalíptico" tuvo un papel destacado el futurismo. Vadim Cherchenevich tradujo el Manifiesto del futurismo al ruso en 1914, cinco años después de su publicación, aunque muchos de los artistas adscritos a este movimiento habían tenido ya acceso a él en su original francés. Con su exigencia de una ruptura radical con el pasado y su exaltación de la juventud, la lucha física y la máquina, el futurismo había necesariamente de encontrar seguidores en un país social y económicamente atrasado. La tradición rusa, escribe Groys, «se asociaba con el atraso y la humillación con respecto a países más desarrollados, y por eso provocaba aversión y no lástima en la mayoría de la intelectualidad y también, como se dejó ver en el curso de la revolución, en el

\footnotetext{
2 Alexander Zinóviev caricaturizaría décadas más tarde esta interpretación de la historia, compartida por muchos bolcheviques: «Estamos comenzando una nueva historia. Pero estamos comenzándola no desde el comienzo, sino desde el final. El comienzo sólo lo alcanzaremos al final. Es por ello que, una vez más [grito]: ¡Abajo la democracia!» (Zinóviev, 1986: 40)
} 
pueblo.» (Groys, 2008: 29) El culto al cuerpo característico del futurismo habría de sentar las bases lo mismo del concepto de hombre nuevo que su representación: «Las imágenes del boxeador y el luchador eran recurrentes en su estética», escribe Juan Agustín Mancebo Roca. «Los hermanos Zdanevich continua- empezaron a asistir regularmente a un gimnasio de musculación y se realizaron algunos cuadros sobre ejercicios de lucha y culturismo: Luchadores, 1908-1909 y Lucha, 1909-1910, de Goncharova, el Retrato de Vladimir Burluik, 1910 y Riña en una taberna, de Larionov, o el explícito Autorretrato con Petr Konchalovsky, 1910, de llia Mashkov (1881-1944) que exaltaba la potencia física de los representados en contraste con un entorno refinado propio de intelectuales y personas vinculadas con la cultura.» (Mancebo Roca, 2007: 113) En este contexto de una completa reestructuración de la vida cotidiana para la reestructuración del hombre mismo, el poeta Serguéi Tretiakov escribió en LEF que la propaganda de la forja del hombre nuevo «es, en realidad, el único contenido de las obras de los futuristas, quienes, fuera de esa idea orientadora, se convirtieron invariablemente en equilibristas verbales (...) La brújula del futurismo desde los días de su niñez no fue la creación de nuevos cuadros, poemas y noveletas, sino la producción de un hombre nuevo utilizando el arte como uno de los instrumentos de esa producción”.» (en Groys, 2008: 86)

Incluso bolcheviques con experiencia política y conocimientos literarios y artísticos como Trotsky -que criticó duramente el afán destructor de los futuristas- se dejaron arrastrar por momentos por el entusiasmo revolucionario. Para Trotsky, el arte nuevo era «incompatible con el pesimismo, con el escepticismo, con todas las demás formas de abatimiento espiritual», "realista, activo, colectivista, de forma vital y henchido de una confianza ilimitada en el porvenir». El hombre nuevo a que daría lugar, "comenzará a armonizar con todo rigor su propio ser. Tratará de obtener una precisión, un discernimiento, una economía mayores, y por ende belleza en los movimientos de su propio cuerpo, en el trabajo, en el andar, en el juego. Querrá dominar los procesos semiinconscientes e inconscientes de su propio organismo: la respiración, la circulación de la sangre, la digestión, la reproducción. Y dentro de ciertos límites insuperables, tratará de subordinarlos al control de la razón y de la voluntad. El homo sapiens, actualmente congelado, se tratará a sí mismo como objeto de los métodos más complejos de la selección artificial y los tratamientos psicofísicos. [...] El hombre se esforzará por dirigir sus propios sentimientos, de elevar sus instintos a la altura del consciente y de hacerlos transparentes, de dirigir su voluntad en las tinieblas del inconsciente. Por eso, se alzará al nivel más alto y creará un tipo biológico y social superior, un superhombre si queréis. [...] El hombre se hará incomparablemente más fuerte, más sabio y más sutil. Su cuerpo será más armonioso, sus movimientos más rítmicos, su voz más melodiosa.» (Trotsky, 1924)

\section{Representando al hombre nuevo}

La construcción de una estética socialista que respaldase estos nuevos conceptos filosóficos no fue, como cabe suponer, una tarea sencilla ni exenta de polémica. Formados, aunque rara vez lo reconocieron, en los dogmas del 
marxismo ortodoxo, el primer problema que encontraron fue la escasez de menciones al arte y la literatura en la obra de Marx y de Engels. ${ }^{3}$ Se buscaron antecedentes en la pintura de Gustave Courbet o llya Repin y el resto de los pintores del grupo de Los Errantes (Peredvizhniki) y en la literatura de Lev Tolstoy, Anton Chekhov o Nikolay Chernyshevsky, uno de los novelistas favoritos de los bolcheviques. Pero sus obras ofrecían sobre todo retratos realistas de las miserables condiciones de vida de la clase obrera de su época, no del hombre que habíase de producir resultado de la transformación socialista de la sociedad. El concepto de hombre nuevo era, cuanto menos, problemático, en tanto que se avanzaba al presente, chocando con el materialismo histórico tal y como lo entendían Marx y Engels. Además, la Unión Soviética estaba rodeada de potencias enemigas e inmersa en una cruenta guerra civil que duró hasta 1923. A todo ello se sumaban los gustos mayoritariamente conservadores de los bolcheviques en materia de arte, que chocaban con los de los artistas rusos influidos por los movimientos de vanguardia europeos.

Irónicamente -irónicamente porque fue fusilado por el mismo régimen que se apropió y distorsionó sus descubrimientos- debemos al dramaturgo ruso Vsevolod Meyerhold la invención de los códigos que habrían de establecer la base visual para la representación del hombre nuevo. Meyerhold rechazó -el dramaturgo alemán Erwin Piscator llegaría a las mismas conclusiones varios años después ${ }^{4}$ el psicologismo de Stanislavski y propuso los personajes fueran convertidos en tipos («máscaras sociales») fácilmente reconocibles gracias a una caracterización convencional que reflejase su distribución desde el punto de vista de la lucha de clases, asignando a cada uno de ellos su propio puesto en esta lucha. Su más famoso discípulo, el cineasta Serguei M. Eisenstein, popularizaría muchas de estas técnicas -que él llamó typage- en sus películas.

Hoy estos tipos pueden parecernos ingenuos, lo mismo en la teoría que en la práctica. No lo eran en la época, no sólo debido al elevado nivel de analfabetismo en la URSS -un país, por lo demás, de más de 20 millones de kilómetros de extensión poblado por 160 millones de habitantes que hablaban

\footnotetext{
${ }^{3}$ Cfr. Karl Marx; Friedrich Engels, Cuestiones de arte y literatura (Barcelona: Península, 1975). Traducción de Jesús López Pacheco.

${ }^{4}$ Aunque se ha acusado repetidamente a Erwin Piscator de haber plagiado las ideas de Meyerhold y otros directores de escena bolcheviques, parece muy improbable que, aún como militante comunista, Piscator conociera de estas experiencias, pero la insistencia en las mismas le obligó a defenderse de estas acusaciones en su obra El teatro político: «se ha sostenido con frecuencia que yo había tomado esta idea de los rusos. La verdad es que entonces me era casi desconocida la situación del teatro de la Rusia soviética. Las noticias de representaciones, etc., nos llegaban siempre con harta escasez. Ni ha llegado después a mi conocimiento que los rusos hayan empleado nunca el cine funcionalmente, como lo he hecho yo. Por lo demás, la cuestión de la prioridad no tiene la menor trascendencia.» (Piscator, 2011: 111) Más adelante Piscator regresa a este debate para proporcionar al lector nuevos argumentos: «Siempre me ha sido indiferente la determinación de prioridades e igual le sucede a mi amigo Brecht principalmente porque nunca tiene en consideración el hecho único y al mismo tiempo recurrente de que ciertas cosas, en cualquier período, están "en el ambiente"; es decir, un descubrimiento físicoquímico puede realizarse simultánea e independientemente en Tokio y en Nueva York. La cuestión no es: ¿qué adoptó fulano (es decir: robó) de zutano?, sino más bien, ¿con qué propósito utilizó este o aquel elemento, y cómo lo desarrolló o lo cambió en relación con los diferentes problemas, circunstancias y necesidades?» (Piscator, 2011: 409).
} 
más de 100 lenguas distintas-, que forzaba a los artistas a una tarea pedagógica y de cohesión política que dejaba poco espacio a creaciones sutiles, sino también como una aplicación de las teorías formalistas que propugnaban el ahorro de energías psíquicas al espectador al identificar inmediatamente a los personajes y poder concentrarse en el desarrollo de la trama. Históricamente ha de leerse también como una reacción a las bienintencionadas, pero simplificadas, descripciones de la clase obrera de los naturalistas europeos así como a las descripciones demofóbicas posteriores a las revoluciones francesas de 1789 y 1792, de las que las caricaturas de George Cruikshank y James Gillray constituyen un excelente ejemplo, y que muestran a las clases populares como una masa desordenada de individuos físicamente desagradables y fuera de toda civilización, y que duraron hasta la segunda mitad del siglo XX -si acaso no perviven en cierto modo todavía en los medios de comunicación-. ${ }^{5}$

La muerte de Lenin el 21 de enero de 1924, y el ascenso de Stalin al poder, consolidado en 1934, cambian el rumbo de la Unión Soviética. Ya el 23 de abril de 1932 el Comité Central decretó la disolución de todas las agrupaciones agrupaciones artísticas, tras la cual todos los "trabajadores creadores" soviéticos debían ser reunidos en "uniones de creadores" únicas con arreglo al género de su actividad: uniones de escritores, de artistas plásticos, de arquitectos y así sucesivamente. Este decreto del Partido, que tenía como objetivo someter toda la práctica cultural soviética a la dirección del Partido, inaugura formalmente una nueva etapa, la estaliniana, en la vida cultural del país, por la cual se subordinó el arte al didactismo social, eliminando los experimentos artísticos sofisticados para las élites urbanas, que eran descalificados alternativamente como "formalistas", "pequeñoburgueses", "decadentes" y "cosmopolitas". El dogma del realismo socialista, definida por Andrei Zhdánov y recogida en los estatutos de la Unión de Escritores Soviéticos como «una representación verídica, históricamente concreta, de la realidad en su desarrollo revolucionario", no fue impuesto sin resistencia y encontramos críticas desde Meyerhold -que calificó el nuevo estilo de «propaganda con demasiada frecuencia estúpida: los personajes esquemáticos que no son más que virtudes, si se trata de "rojos", y defectos, si se trata de "blancos"» (Meyerhold, 2008: 278)- al teórico húngaro Georg Lukács, quien la tachó de "naturalismo burocrático" y "ortodoxia naturalista" estalinista. (Lukács, 1981: 165) La prioridad política otorgada al contenido se tradujo no solamente en el abandono de la experimentación vanguardista en favor de un estilo visual

\footnotetext{
${ }^{5}$ "Que el público es de una ralea sucia y fastidiosamente repulsiva. Que el pueblo es estúpido, una eterna raza de esclavos que no puede vivir sin yugo ni bastón", Leconte de Lisle. "Cabezas piojosas, cuellos grasientos, pelo embetunado, los chiflados, los domadores de caracoles, los sabiondos de pueblo, todos los descontentos, los desclasados, los tristes, los retrasados, los incapaces», Téophile Gautier. «Pasaban las masas ya revueltas; mujerzuelas feas, jorobadas, con lazos rojos en las greñas, niños anémicos y sucios, gitanos, cojos, negros de los cabarets, rizosos estudiantes mal alimentados, obreros de mirada estúpida, poceros, maestritos amargados y biliosos. Toda la hez de los fracasos, los torpes, los enfermos, los feos; el mundo inferior y terrible, removido por aquellas banderas siniestras", Agustín de Foxá. Son algunos de los ejemplos literarios de demofobia posterior a la "primavera de los pueblos" de 1848, la Comuna de París de 1871 y la victoria del Frente Popular en la España republicana de 1936 contenidos en Antoni Domènech, El eclipse de la fraternidad. Una revisión republicana de la tradición socialista (Barcelona: Crítica, 2004).
} 
más inmediato -y por ello necesariamente más conservador-, sino también en el de los anteriores temas de la revolución, la lucha de clases y la lucha armada por los de la "edificación del socialismo". En el centro de esta cultura se levantó la "imagen del hombre nuevo" siguiendo la llamada de Andrei Zhdánov: "Hay que sacudirse el viejo Adán y empezar a trabajar como trabajaban Marx, Engels, Lenin, y como trabaja el camarada Stalin.» (en Groys, 2008: 118) En su discurso ante el Primer Congreso de la Unión de Escritores Soviéticos, Zhdánov desarrollaba esta consigna como sigue:

«En nuestro país, los héroes principales de las obras literarias son los activos constructores de una vida nueva: los obreros y las obreras, los hombres y las mujeres de las granjas colectivas, los miembros del Partido, los administradores, los ingenieros, los miembros de la Liga de Jóvenes Comunistas, los pioneros. Estos son los caracteres básicos y los héroes básicos de nuestra literatura soviética. Nuestra literatura destila entusiasmo y heroicidad. Es optimista y no debido a algún instinto interno de origen biológico. Es optimista en esencia puesto que es la literatura de la clase emergente del proletariado, la única clase avanzada y progresista. Nuestra literatura soviética es fuerte porque sirve a una nueva causa, la causa de la construcción socialista." 6

Este hombre nuevo, según lo describe el sociólogo albanés Artan Fuga, había de ser «un tipo social que por lo que se refiere a la formación ideológica, la preparación científica y profesional, las cualidades del carácter y los valores morales, los vínculos sociales que mantenía con el medio al que pertenecía y con la sociedad en general, no tenía precedente en el pasado.» Este hombre nuevo no «conocía la fe ni la creencia religiosas; adjudicaba prioridad al interés del colectivo, de la sociedad y de la nación frente a su estrecho interés personal y familiar; no reconocía ni aceptaba relaciones de propiedad privada sino que obraba únicamente en el marco de una igualdad material y económica fundamentada sobre la propiedad de todos; no estaba influido por ninguna suerte de superstición mistificadora sino que se inclinaba tan sólo a una explicación racionalista del mundo apoyada en el pensamiento materialista; un ser solidario, con iniciativa, crítico ante todo lo conservador, inconmovible en la confrontación con los burócratas y enemigos de clase; un "animal político" que adopta como brújula de su vida el criterio político proletario»; y se contraponía al individuo medio de la sociedad occidental, «al que se presuponía imbuido de inclinaciones egoístas, ideológicamente confuso, un ser carente de solidaridad, sometido a una jerarquía social fundada en la diferenciación de clase.» Este hombre nuevo, concluye Fuga, era un «ser por tanto moralmente puro, armónicamente desarrollado en lo físico, que había superado las limitaciones del tipo humano de los tiempos pretéritos y del que habitaba en la sociedad occidental.» (Fuga, 2002: 187)

Se osificaron, en consecuencia, los "tipos sociales" que representaban al "hombre nuevo" del socialismo así como a los pilares del nuevo estado obrero y campesino que encontraremos repetidos ad nauseam, a saber: el soldado, el obrero industrial y el campesino (o, más exactamente, la campesina, porque

\footnotetext{
${ }^{6}$ Andrei Zhdánov, "La literatura soviética es la más ideológica, la más vanguardista del mundo", discurso ante el Primer Congreso de la Unión de Escritores Soviéticos, Moscú, 1934.
} 
casi siempre es representada como mujer). Así aparece, por ejemplo, en la conocida obra de Vera Mukhina, Obrero y campesina de koljós, de 1937, que coronó el Pabellón Soviético en la Exposición Internacional de París de 1937 y más tarde fue utilizada como sello de Mosfilm, una de las productoras cinematográficas propiedad del estado. Más adelante también veremos la aparición de las figuras del intelectual orgánico, el ingeniero y el científico, el cuadro del partido, el atleta y, a partir de los sesenta, el cosmonauta, todos ellos bajo la estricta vigilancia del dirigente político. Las cualidades de todos ellos, muy por encima de las del hombre común, como ha escrito Boris Groys:

«Un rasgo característico de los héroes de la literatura del período de Stalin es la capacidad de realizar hazañas que de manera evidente superan las fuerzas humanas: esta capacidad se manifiesta en ellos gracias a su negativa a abordar la vida "formalistamente". Esta negativa les permite, con la sola fuerza de la voluntad, curarse de la tuberculosis, comenzar a cultivar plantas tropicales en la tundra y sin invernaderos, paralizar al enemigo con la sola fuerza de la mirada, y así sucesivamente. El movimiento stajanovinista, sin ninguna aplicación adicional de la técnica, con la sola fuerza de voluntad de los trabajadores, elevó la productividad del trabajo decenas de veces. Sin ninguna aplicación de los "métodos formalistas de la genética", el académico Lysenko logró convertir unas especies de plantas en otras completamente distintas. [...] Como modelo de tal "voluntad de acero [stal'nol]" se consideraba al propio Stalin, para el cual prácticamente no había nada imposible, porque, como se creía, él solo, con esa voluntad suya, movía todo el país.» (Groys, 2008: 122)

A pesar de todo utopismo, este hombre nuevo socialista no podía surgir de la nada, de ahí la función de los ejemplos que se pretendía actuasen como "héroes positivos", modelos a imitar por el pueblo soviético. Así, en el campo del trabajo encontramos al obrero Máximo de la trilogía cinematográfica de Grigori Kozintsev y Leonid Trauberg de la década de los treinta o el esforzado minero Aleksei Stajánov; en el ejército, al valeroso comandante del Ejército Rojo, inmortalizado por la novela de Dimitri Furmánov, Vasily Chapaev; y así sucesivamente, lo que llevó paradójicamente al realismo socialista, escribe Román Gubern (2004: 302), «a enfeudarse en la tradición romántica, contradiciendo sus premisas teóricas.» A propósito de estas representaciones de entrega hasta el sacrificio, Susan Buck-Morss escribe que «el lado oscuro de la monumentalidad del estilo estalinista era el castigo corporal a los propios trabajadores, con sonrisas estáticas que expresaban placer ante el dolor físico.» (Buck-Morss, 2004: 205) ${ }^{7}$ Como antítesis de los anteriores aparecieron

\footnotetext{
${ }^{7}$ En su fábula antiestalinista Rebelión en la granja, George Orwell atribuyó al caballo Boxer las características de trabajadores como Stajánov. "Boxer -escribe- era una bestia enorme, de casi quince palmos de altura y tan fuerte como dos caballos normales juntos. Una franja blanca a lo largo de su hocico le daba un aspecto estúpido, y, ciertamente no era muy inteligente, pero sí respetado por todos dada su entereza de carácter y su tremenda para el trabajo.» Más adelante, cuando los animales deciden construir un molino en la granja, el escritor describe así la participación de Boxer: «Verlo arrastrando hacia arriba por la pendiente, pulgada tras pulgada, jadeante, clavando las puntas de sus casos en la tierra, y sus enormes flancos sudorosos, llenaba a todos de admiración. Clover a veces le advertía que tuviera cuidado y no se esforzara demasiado, pero Boxer jamás le hacía caso. Sus dos lemas: "Trabajaré más fuerte" y "Napoleón [Stalin] siempre tiene la razón", le parecían respuesta satisfactoria para todos los problemas. Se había puesto de acuerdo con el gallo para que éste lo despertara por la mañana tres cuartos de hora más temprano, en vez de media hora. $Y$ en sus ratos libres, de
} 
el burgués, el aristócrata (durante la guerra civil de 1921-1923, bajo la forma de general blanco), el "renegado", el pope ortodoxo, el kulak y el saboteador (durante la disolución de la Makhnovshchina en Ucrania oriental a manos del Ejército rojo durante los años 1920-1921, esta figura tomó la forma de anarquista terrorista en una burda operación de propaganda contra los anarquistas que paralelaba la de la prensa burguesa). Las cualidades de éstos son, como no cabía sino esperar, un negativo fotográfico de la de los héroes positivos:

«La figura del "saboteador", tan importante para la mitología estaliniana, en realidad no tiene ninguna "motivación realista" común, del mismo modo que no la tiene la fuerza creadora sobrehumana en el "héroe positivo". En los procesos ejemplares estalinianos se demostraba que personas de apariencia totalmente normal resultaban capaces de echar vidrio en la comida de los trabajadores, inocularles viruela y erisipela, envenenar las cisternas, rociar tóxicos en lugares públicos, provocar la mortandad del ganado, y así sucesivamente. Y todo eso en escalas completamente sobrehumanas, inimaginables, hallándose simultáneamente en los más diferentes lugares y realizando simultáneamente las acciones más titánicas con su potencia destructiva, pero, al mismo tiempo, una vez más, sin ninguna ayuda ni organización (porque, de lo contrario, se les quitaría la culpa individual), prácticamente con el solo esfuerzo de la voluntad (porque ellos se halaban todo el tiempo bajo control y haciendo trabajo del Partido).» (Groys, 2008: 124)

En el extremo, los "enemigos del pueblo" eran condenados a lo que Juan Agustín Mancebo Roca ha definido como una "muerte doble": "por un lado la muerte física, que generalmente quedaba constatada como una desaparición; por otro, la más terrible eliminación de la memoria, la supresión de cualquier vestigio, de cualquier huella de la materialidad del cuerpo [...] la verdadera condena era aquella del olvido, la que hacía a sus semejantes y a todos los espectadores olvidar partes de las fotos y fragmentos cinematográficos.» (Mancebo Roca, 2007: 142) El historiador británico David King ha llegado a reunir en su archivo 250.000 imágenes manipuladas por el estalinismo entre 1923 y 1953, fecha de la muerte de Stalin. (Gubern, 2004: 299) ${ }^{8}$

El realismo socialista, que estaba llamado a educar a las masas, ahuyentaba con su rígido funcionalismo social (que mutilaba toda individualidad), su tono de maestro de escuela (fatalmente apologético, paternalista y simplista), su incapacidad de entretener y su completa desvinculación de la vida real, a esas mismas masas que pretendía alcanzar. Algunos disidentes, como Alexandrer Zinóviev, comenzaron a hablar, en tono sarcástico, de la creación un homo sovieticus -Zinóviev propuso, siguiendo un uso lingüístico habitual en la política soviética, el acrónimo homosos- que más bien habría de caracterizarse por ser un negativo fotográfico del ideal del "hombre nuevo", a saber: falto de toda iniciativa y convicción, indiferente hacia el resultado de su trabajo y el bien

los cuales disponía muy pocos en esos días, se iba a la cantera, juntaba un montón de pedazos de piedra y lo arrastraba por sí solo hasta el emplazamiento del molino.» George Orwell, Rebelión en la granja (Barcelona, Destino, 1997). Traducción de Rafael Abella.

${ }^{8}$ Alan Jaubert recoge en su libro, Le comissariat aux archives. Les photos qui falsifient l'histoire (Paris, Barrault, 1986), además de numerosos casos de manipulación en la URSS, ejemplos de Albania, Bulgaria, China, Corea del Norte, Cuba, Checoslovaquia y Yugoslavia, entre otros. 
común, provinciano como consecuencia de su aislamiento de la cultura mundial, siendo casi todo lo anterior la consecuencia de una obediencia ausente de crítica o aceptación pasiva ante una gigantesca burocracia en la cual busca integrarse de manera oportunista y carrerista. Zinóviev describió gráficamente al homo sovieticus como un «reaccionario extremista viajando en el vagón del progreso extremista»:

«Tomemos, como ejemplos, a los homosos que están viviendo hoy en Moscovia. Los precios de los alimentos han subido. ¿Organizarán los homosos una manifestación en protesta? Por supuesto que no. Los homosos han sido entrenados a vivir en condiciones verdaderamente terribles. Está dispuesto a enfrentarse a las dificultades. Continuamente espera algo incluso peor. Se achica ante las disposiciones de los poderes fácticos. ¿Cómo se comportará el homosos si tiene que adoptar una postura en público (esto es, en las reuniones, en su colectivo) hacia los disidentes? Naturalmente, apoyará las acciones de las autoridades y condenará las acciones de los disidentes. El homosos siempre trata de poner un palo en las ruedas de cualquiera que trate de interrumpir las formas acostumbradas de comportamiento; adula a los poderes fácticos; está del lado de la mayoría de sus conciudadanos que son aprobados por las autoridades. ¿Cómo reaccionan los homosos a la militarización de su país y al crecimiento de la actividad soviética en el mundo, incluyendo sus tendencias intervencionistas? Apoyando por completo a su liderazgo, porque posee la conciencia estandarizada formada por la ideología, un sentimiento de responsabilidad por el país como un todo, una disposición al sacrificio y una disposición a sacrificar a otros. Por supuesto el homosos es también capaz de sentir descontento hacia su colectivo: incluso puede criticar lo que está sucediendo en el país y a las autoridades. Pero sólo en la forma apropiada, en el lugar apropiado y en el grado apropiado; esto es, de un modo que no amenace apreciablemente los intereses generales del organismo social. Incluso en este campo uno puede especificar las situaciones características y el comportamiento característico de los homosos. De una serie de cuestiones reveladoras de carácter y sus respuestas, obtendréis una descripción de un hombre adecuado a los requisitos de la sociedad socialista (comunista) y apropiada a ésta desde el punto de vista de su integridad y sus intereses como un todo. [...]

«El homosos evolucionado no es decadente. Por el contrario, es el producto más elevado de la civilización. Es el superhombre. Es universal. Si es necesario, puede acometer cualquier temeridad. Donde es posible, puede poseer toda virtud. No hay secretos que no pueda explicar. No hay problemas que no pueda resolver. Es inocente y simple. Es vacío. Omnisciente y omnipresente. Repleto de sabiduría. Una partícula del universo que contiene el universo entero. Dispuesto para cualquiera y para cualquier cosa. Está incluso preparado para lo mejor. Lo espera, aunque no cree en ello. Espera lo peor. No es nada, lo que es tanto como decir: lo es todo. Es Dios pretendiendo pasar por el diablo. Es el diablo pretendiendo pasar por Dios. Está en cada hombre.» (Zinóviev, 1986: 40 y 258-260)

Poco sorprendentemente, el estalinismo, al menos artísticamente, comenzó su declive con la muerte de su artífice en 1953 y se derrumbó rápidamente tras el 
informe secreto del XXo Congreso del PCUS en 1956 -del cual fueron excluidos los delegados chinos-y el deshielo jruschoviano, pero sobrevivió en la República Popular China y los países del sudeste asiático que adoptaron su modelo, mientras en los países de Europa oriental, Cuba y Yemen del Sur, así como los partidos comunistas de Europa occidental y Latinoamérica, tomaron diferentes caminos estéticos. Con todo, la influencia y el deseo de reflejarse en las conquistas de la Unión Soviética -al menos así eran percibidas- llevó a asumir inconscientemente muchos de los postulados de aquélla -incluido el tema del 'hombre nuevo'-. Carlos Widmann (2010: 56-58) define al Che Guevara como

«un personaje de leyenda que se inventó y se creó a sí mismo. [...] no sólo el ambiguo Mesías de la industria de los pósteres, sino toda esa exhibición de la propia individualidad a la que el Che, con su talento para posar, sacó tanto rédito desde su más temprana juventud. El escolar de gesto enfurruñado y pensativo, tumbado en un balcón, con las manos bajo la nuca. El osado estudiante de secundaria que cruza un abismo, balanceando sobre una tubería. El futuro médico en la clase de anatomía, que sonríe descaradamente ante el cadáver de un viejo desnudo. Che jugando al rugby, haciendo alpinismo, montando una moto. Che en un planeador, o fumando un puro, o bebiendo mate. Hasta en su misión secreta en el Congo, Guevara se ocupó de que hubiera fotógrafos presentes. Y cuando no podía ser, como en el hotel en Bolivia donde se alojó clandestinamente en 1966 -con el nombre de Adolfo Mena, un uruguayo medio calvo y con gafas-, él mismo se fotografiaba delante del espejo. Ningún episodio de su heroica epopeya debía quedar sin documentación gráfica. El Che parecía preferir ser retratado con el torso desnudo, incluso para una publicación como Playboy. [...] cuando la pareja [Jean-Paul Sartre y Simone de Beauvoir] visitó Cuba [...], el filósofo del existencialismo nombró al Che viviente como "el ser humano más perfecto de esta era". O sea: un hombre que irrumpe de la selva con un rifle en la mano y se convierte en el presidente del Banco Nacional de Cuba.»

\section{El hombre nuevo en China}

La proximidad de los dirigentes comunistas chinos con sus camaradas rusos, y las similitudes estructurales del país (economía rural, elevado índice de analfabetismo), llevó a éstos a la asunción de la mayor parte de sus fórmulas, desde la imagen de la naciente sociedad comunista como una tabula rasa o, por expresarlo con palabras del propio Mao, «una hoja de papel en blanco, desnuda, [en la que] se pueden escribir las palabras más nuevas y hermosas y pintar los cuadros más originales y bellos» hasta el salto por encima de la historia -«debemos realizar entre el pueblo una propaganda constante sobre los progresos del mundo y su futuro luminoso, para que adquiera confianza en la victoria»- y la sobrestimación de los actos volitivos - «los revolucionarios pueden, mediante sus esfuerzos, superar gradualmente las dificultades y crear una situación nueva, favorable»-(Mao, 1976: 38, 209, 203). Por supuesto, todo ello, como ocurrió antes en la Unión Soviética, se trasladó a lo estético. Así, el 2 de mayo de 1942 en el foro de Yenan -que fue en cierto modo el correlato del 
decreto del 23 de abril de 1932 del Comité Central en la Unión Soviética, en sancionar cómo debería ser a partir de aquel momento el arte socialista-, el presidente Mao afirmó que «las luchas revolucionarias en el frente ideológico y artístico tienen que subordinarse a la lucha política» (en Gubern, 2004: 315), lo que se tradujo previsiblemente en una subordinación de la forma artística al contenido, al que servía de forma toscamente funcionalista según la consigna "hong, guang, liang" (rojo, brillante y deslumbrante). El realismo socialista chino adaptó a las tradiciones artísticas del país un modelo que había demostrado claramente su eficacia en la Unión Soviética, en línea con el proceso de "sinificación del marxismo" (Makesizhuyi) emprendido por el PCCh. Que muchas de las manifestaciones de la cultura nacional-popular china, como las tramas teatrales, girasen con frecuencia en torno a las reivindicaciones de justicia social de los campesinos frente a los terratenientes, no facilitó sino la tarea de la elaboración de un canon para el realismo socialista chino, que acentuó, sobre todo durante su primera fase, el componente campesino, en consonancia con la estructura social de un país en el que la agricultura intensiva de irrigación había sido el tradicional modo de subsistencia y que contaba en la primera mitad del siglo una población de quinientos millones, rural en un $90 \%$ y específicamente campesina en un $80 \%$. (Poch, 2009: 25) La estrategia de los comunistas chinos pasaba, pues, ineludiblemente por ganarse el favor del campesinado, un sector que a ojos de los comunistas carecía de consciencia nacional y de clase y no había protagonizado hasta la fecha más que protestas sociales de carácter reactivo. La revolución trajo consigo el reparto de tierras y en la China central y meridional, donde el $40 \%$ de la tierra estaba en manos de terratenientes, su redistribución benefició al $60 \%$ de la población de una u otra manera. (Poch, 2009: 27) «En consecuencia, se necesitaba una revolución cultural», escribe Liu Kang, "para fomentar la conciencia de clase entre el campesinado. Habida cuenta de que los campesinos eran esenciales para el triunfo de la revolución en ausencia de un proletariado urbano numeroso y organizado, la llamada "línea de masas" se convirtió en la estrategia central», lo que explicaría, según este autor, la sobrestimación de los factores culturales en detrimento de la transformación política y económica mencionada al comienzo de este parágrafo, una idea introducida en el marxismo chino por Qu Qubai que Mao perpetuó y ahondó, reduciéndola a una rígida doctrina que consolidaba la dicotomía entre política y estética. (Kang, 2000: 44, 66, 93) Este hecho, sin embargo, puede verse además como resultado de la situación de la República Popular China tras su proclamación en 1949:

«Debido a que las condiciones históricas tomaron un giro decisivo en este momento, Mao no cambió realmente demasiado sus estrategias. A pesar de su aguda perspicacia de la transición histórica, y de sus propias peticiones a favor de una transformación estratégica, Mao aún había de cambiar de marcha, por así decir, pasando de maniobras de guerra a la planificación de la reconstrucción económica y social. De hecho, Mao nunca abandonó realmente su táctica y perspectiva militares durante su gobierno, incluso aunque los objetivos principales cambiaron fundamentalmente de la destrucción violenta a la construcción pacífica tras el establecimiento de la República Popular China. Por supuesto, la nueva China estaba aún rodeada de fuerzas hostiles, lo mismo internas que externas. Taiwan había sido ocupada por Chiang Kai-shek, 
apoyado por los Estados Unidos en su estrategia posterior a la Segunda Guerra Mundial de contención del comunismo. En el primer año del nuevo régimen, uno de los principales objetivos de Mao fue conquistar la isla, pero estalló la Guerra de Corea. El consiguiente bloqueo del estrecho de Taiwan por la Séptima Flota de los EE.UU. y las soflamas de Chiang Kai-shek sobre la reconquista de la China continental ayudaron a intensificar el pánico y el miedo que el nuevo régimen experimentaba. Bajo estas circunstancias, la necesidad de combatir a los "enemigos con fusiles" continuó, mientras la lucha contra los "enemigos sin fusiles", según los cálculos de Mao, había de comenzar en las ciudades inmediatamente en el "frente cultural" para conquistar por entero el país y consolidar su victoria. Una cierta cantidad de determinismo fue necesaria, en un sentido estratégico, para hacer frente a una enorme cantidad de problemas prácticos. Lo que, traducido en medidas prácticas, simplemente significó la supresión determinada e implacable de toda la oposición política. [...] El binarismo estuvo directamente vinculado a la ideología de la guerra fría, y fue en primer lugar una sangrienta batalla a vida o muerte antes que cualquier otra cosa discursiva o retórica.» (Kang, 2000: 27-28)

Sin embargo, con la sola excepción de la reforma agraria de 1950, la política comunista volvió a cometer en China buena medida los mismos errores que en la Unión Soviética, generando divisiones sociales:

«El nuevo régimen -escribe Rafael Poch- les utilizó para realizar la acumulación primitiva de capital necesaria a la industrialización y el desarrollo de la "base social" industrial del nuevo orden "socialista". La relación con los campesinos fue tensa, pero la diferencia con el pasado era que el Estado, por primera vez en la historia china, había llegado hasta el último pueblo y el último rincón del país. Se metía en la vida cotidiana e incluso "expropiaba" autoridad al cabeza de familia, contribuyendo así a una considerable transformación patriarcal, particularmente importante para las mujeres, que se liberaron, con la nueva ley matrimonial, de gran parte de su ancestral postración. La lealtad y la obediencia debidas al régimen se hicieron superiores, y en parte disolvieron, a la tradicional jerarquía familiar. El control, la disciplina y la capacidad de organización colectiva alcanzaron niveles sin precedentes, que hicieron posible infinidad de obras públicas locales y afirmaron mínimos generales de subsistencia.

«A partir de 1953, se obligó a los campesinos a vender el 25 por 100 de su producción al Estado a precio muy bajo, lo que permitió el abastecimiento de comida a las ciudades. Aquella medida fue preludio a la colectivización, primero con las cooperativas de producción de 1954, y luego, en 1958, con las comunas populares, el sistema mantenido hasta 1978. Emigrar a las ciudades, donde imperaba una vida mucho mejor, era como "escalar el cielo", afirmaba el dicho de la época [...] La lógica de ese sistema era que la revolución industrial de China, basada en la ciudad, sólo podía realizarse sobre las espaldas de los campesinos.» (Poch, 2009: 27-28)

Consecuencia de todo lo anterior fue que el realismo socialista chino no varió prácticamente en nada los tipos sociales del realismo socialista soviético, que se establecieron siguiendo textos que trataban de dibujar -con contornos muy imprecisos, como puede fácilmente verse- la estructura de clases del país, como el "Análisis de las clases de la sociedad china" de Mao de 1926, recogido 
en el Libro rojo y que varió muy poco con el tiempo:

«Son nuestros enemigos todos aquellos que están confabulados con el imperialismo: los caudillos militares, los burócratas, la burguesía compradora, la clase de los grandes terratenientes y el sector reaccionario de la intelectualidad subordinado a todos ellos. El proletariado industrial es la fuerza dirigente de nuestra revolución. Nuestros amigos más cercanos son el semiproletariado en su totalidad y la pequeña burguesía. En cuanto a la vacilante burguesía media, su ala derecha puede ser nuestro enemigo, y su ala izquierda, nuestro amigo; pero debemos mantenernos constantemente en guardia y no permitir a esta última que cree confusión en nuestro frente.» (Mao, 1976: 15)

Así pues, en la propaganda china habremos de encontrar al soldado, al obrero industrial, al campesino, el intelectual, y así sucesivamente, todos los cuales, como escribe Stefan R. Landsberger, declaraban «su obediencia al presidente Mao Tse Tung o se dedicaban a la gloriosa tarea de reconstruir el país.» El objetivo de esta propaganda, prosigue Landsberger, era «glorificar el trabajo y el sacrificio personal en aras de un bienestar superior» y en consecuencia «mostraban un escaso interés por la dimensión personal y privada de la vida de las personas, fuera el descanso o la diversión.» $Y$ a propósito de su representación, añade:

«Los cuerpos fuertes y saludables de los personajes de los carteles eran una metáfora de las clases productivas, igualmente fuertes y saludables, que el estado quería afianzar. En el proceso, las distinciones entre sexos terminaron por ser erradicadas: las diferencias físicas entre hombres y mujeres prácticamente desaparecieron, algo que también se intentó en la vida real. Ambos géneros presentaban un aspecto estereotipado y "masculinizado" que casi les hacía parecer sobrehumanos. Llevaban ropa amplia y asexuada, siendo los únicos colores disponibles el gris (para funcionarios), el verde (para militares) y el azul (para obreros y campesinos) Sus rostros, incluidos el pelo cortado a lo paje y las pequeñas coletas, se ajustaban a un repertorio limitado de formas estándar aceptables.» (Landsberger, 2003: 17)

A su vez, los nacionalistas del Kuomintang (KMT), los terratenientes, los campesinos ricos, los funcionarios del antiguo régimen, los burócratas e intelectuales burgueses en el seno del Partido -los "enemigos con estilográficas" que vinieron a substituir a los "enemigos con fusiles"- y los imperialistas japoneses, estadounidenses e ingleses así como sus colaboracionistas chinos se convirtieron en la antítesis de aquéllos, siguiendo, una vez más, el modelo soviético. Pero, en contra de lo que pudiera parecer hoy, estas representaciones gozaron de una tremenda popularidad en la República Popular China de la época:

«Su infiltración en todos los niveles de organización y convivencia social, incluidos los más humildes, era un hecho: los pósteres multicolores podían verse adornando las paredes de oficinas y fábricas, casas particulares y dormitorios. A muchas personas les gustaban por su composición y contenido visual, y no prestaban excesiva atención a los eslóganes impresos debajo. De esta manera, el mensaje político de los mismos se asumía de un modo prácticamente subconsciente.

«Se contrató a los artistas de más talento para que plasmaran las tendencias 
políticas de la época de manera bastante detallada. Muchos de ellos eran responsables de los calendarios comerciales que tan populares habían sido antes de la proclamación de la República Popular. Pronto fueron nombrados para algún cargo y entraron a formar parte de las diversas organizaciones que el gobierno y el partido crearon para la producción de carteles propagandísticos. Al fin y al cabo, eran expertos en técnicas de diseño y capaces de visualizar un producto de forma atractiva desde el punto de vista comercial. Las imágenes que proponían solían ser figurativas y realistas, casi como si hubieran copiado una fotografía. Su objetivo era retratar el futuro desde el presente: mostrar la vida no sólo "como es", sino también "como debería ser". Su estilo era ingenuo, con contornos negros y formas pintadas de rosa, rojo, amarillo, verde y azul brillantes. Esta sobras crearon una especie de "realidad-ficción", un híbrido encargado de destacar los efectos positivos y disimular los negativos.» (Landsberger, 2003: 17)

Una vez más, esta estética no fue impuesta sin protesta, y Hu Feng -detenido en 1955, liberado en 1979 y rehabilitado un año después-criticó en su célebre "Informe sobre la práctica y el estado del arte y la literatura en los últimos años" (Guanyu ji nianlai wenyi shijian qingkuang de baogao), también conocida como "La carta de trescientas palabras" (anshiwan yan shu), la tendencia del nuevo arte, cuyas características resumió en "cinco dagas teóricas" que sofocaban el pluralismo y homogeneizaban las formas y estilos artísticos, a saber: «La "visión del mundo comunista perfecto" como condición previa para la creación artística; el foco en la "vida de los trabajadores, campesinos y soldados" como únicas fuentes de representación estética, excluyendo otros aspectos de la vida social; "la reforma de pensamiento" como condición previa para la creación artística; el privilegio exclusivo de las formas tradicionales y nacionales en detrimento de la cultura internacional y cosmopolita; y, finalmente, "la prioridad otorgada al tema". La idea clave del enfoque de Hu era que el partido no debería determinar y dictar las creaciones artísticas y el trabajo cultural, que debería tener por el contrario su propio espacio, relativamente autónomo. Hu afirmó que una visión del mundo comunista, la reforma del pensamiento y la forma nacional eran condiciones necesarias, pero no suficientes, y no digamos ya absolutas, para el trabajo estético.» (Kang, 2000: 121)

El cartel didáctico de 1976 de Zheng Naobin, editado por el Comité de Compilación de Material Didáctico para la Escuela Primaria y Secundaria de Shanghai para ser utilizado para la educación ideológica, titulado La bandera roja del partido, quizás sea el más representativo. En él aparecen, de arriba abajo, como inmortalizados en mármol, un panteón de héroes del socialismo que habían de funcionar como modelos para el hombre nuevo del socialismo: Liu Hulan, Dong Chunrui, Huang Jiguang, Wang Jinxi y Lei Feng. Liu Hulan (1932-1947) fue una joven comunista que a los 15 años fue decapitada en la plaza del pueblo por las tropas del Kuomintang, que el 12 de enero habían la aldea en respuesta al asesinato del alcalde de Yunzhouxi, leal al KMT. Hulan, que había organizado la resistencia, antes de morir gritó: «Mientras viva, seguiré luchando por el pueblo.» De ella dijo Mao: « ¿Una gran vida! ¡Una muerte gloriosa!» Liu Hulan sirvió al partido para captar a la población rural y reforzar el PCC. En 1957 se erigió un memorial en Wenshuixian, provincia de Shanxi. Dong Chunrui (1929-1948) fue un soldado del Ejército Popular de 
Liberación que, en una batalla contra las tropas del KMT en mayo de 1948, tenía la misión de dinamitar un búnquer que se encontraba sobre un puente y eliminar las defensas de los enemigos para una ofensiva. Sin embargo, Chunrui no encontró ninguna posibilidad de fijar la carga explosiva debajo del puente. Como el tiempo apremiaba, se metió debajo de éste, levantó la carga, la presionó contra el puente y tiró del detonador mientras gritaba «¡Por una China nueva! ¡Adelante!» Tras su muerte se hizo célebre como "héroe en combate" y "comunista ejemplar" y su sacrificio se inmortalizó en el cartelismo, la estatuaria y en una película de Guo Wei de 1955 que llevaba por título su nombre y que se alzó con el premio a la mejor película del Ministerio de Cultura en 1957. ${ }^{9}$ Huang Jiguang (1930-1952) fue un soldado del Ejército de Voluntarios de China en la guerra de Corea, miembro de la Liga Juvenil de la Nueva Democracia. En una importante batalla de la campaña de Sangkumryung, estando ya gravemente herido, se lanzó delante de un puesto de artillería después de haber usado todas sus granadas de mano. Después de muerto, fue admitido a título póstumo en el PCCh y recibió las distinciones de "Héroe especial del Ejército de Voluntarios de China" y "Héroe de la República Democrática Popular de Corea". El nombre de Wang Jinxi (1923-1970) está estrechamente ligado a Daqing, el campo petrolífero creado en 1960 al noreste de China. Nacido en el seno de una humilde familia campesina, en la construcción de ese campo de petróleo, Wang, que con 15 años había comenzado a trabajar en el sector petrolífero, consiguió resultados excepcionales en el desarrollo de la extracción de petróleo en China al frente del equipo de perforación número 1205, trabajando en ocasiones con temperaturas de 20 y 30 grados bajo cero. Wang Jinxi -sin duda: el homólogo chino de Stajánov - ha quedado inscrito en la historia del país como el "hombre de hierro Wang". El 8 de octubre 2003 se inauguró un memorial a su figura. ${ }^{10}$ (Otros ejemplos, como An Yemin (1938-1958), un marino comunista de extracción campesina que murió como consecuencia de las graves quemaduras causadas durante una batalla naval contra las fuerzas del KMT en la isla de Jinmen, a pesar de las cuales permaneció en su plaza de artillería durante cuarenta minutos hasta que el combate se resolvió a favor del EPL, tuvieron menos suerte y sus figuras se vieron oscurecidas por las anteriores restantes a partir de 1979.)

El hombre nuevo no fue cuestión, empero, limitada a la propaganda. El hombre nuevo había de surgir no solamente de los modelos positivos no sino por destilación, por así decir, del viejo. De ahí las purgas en todas sus variantes: desde las "sesiones de lucha" (pidou dahu) -en las que se denunciaba y humillaba públicamente a antiguos terratenientes, opositores políticos e infractores de la línea del partido y que en algunos casos llegaron a contar con

\footnotetext{
${ }^{9}$ En el 2007 Guo Wei cuestionó, sin poner en duda el heroísmo de Chunrui, la veracidad de los hechos en un artículo para Popular Cinema. Según Wei, de hecho «nadie fue testimonio personalmente de la escena en que alzó la carga de explosivos: se trataba por completo de una conjetura basada en indicios.». Joel Martinsen, "Memories vs. historical fact: Guo Wei on Dong Cunrui", Danwei.org, 16 de abril de 2007. <http://www.danwei.org/scholarship_and_education/dong_cunrui.php>

${ }_{10}$ Todas las biografías están parcialmente extraídas de Anchee Min, Duo Duo y Stefan R. Landsberger, Chinese propaganda posters (Colonia: Taschen, 2003), p. 28. Traducción de Lidia Álvarez Grifoll y Meritxell Tena Ripollès.
} 
100.000 asistentes- a las interminables autocríticas (jiantao), una importación de la samokritika estalinista que en ocasiones iba tan lejos como para investigar los antecedentes "de pensamiento, familia y clase" en tres generaciones. "Como se vio después», escribe Kang, «la popularización a través de una forma nacional no fue solamente un proceso de creación estética; fue en primer lugar y ante todo un proceso de transformación política, ideológica y moral: un proceso en el que los intelectuales urbanos redimirían sus almas impuras a través de la inmersión en la vida campesina. Mao describió con frecuencia a los campesinos de manera moralizante: sus "manos están sucias, sus pies están sucios de estiércol de vaca." Con todo, Mao creía que sus almas eran mucho más puras que la de los intelectuales pequeñoburgueses. La fábula de Mao de intelectuales impuros versus campesinos puros prácticamente lo presentó como una figura crística, un santo redentor que podía purificar las almas impuras.» (Kang, 2000: 90) Almas como las de Lei Feng.

\section{Lei Feng: "Mao et moa"}

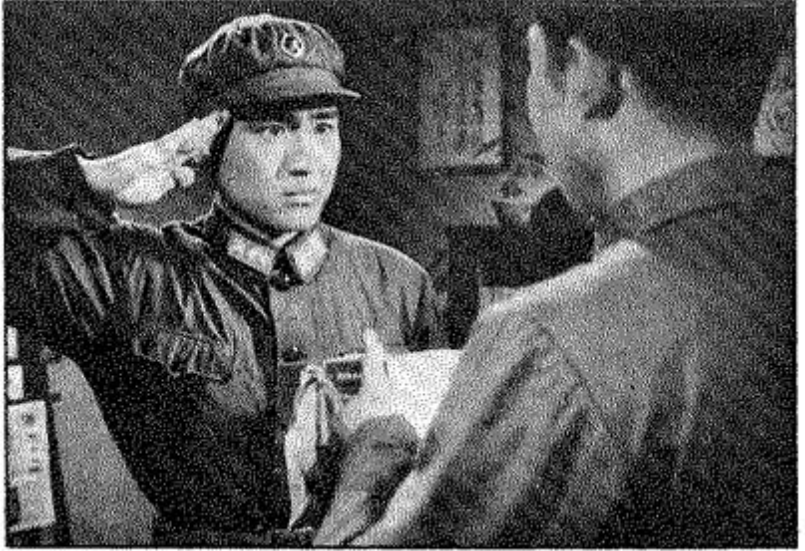

EL INSTRLCTOR SACA DE LN CATON LOS CLATRO VOLL'MENESDE LAS "OBRAS ESCOGIDAS DE MAO TSE-TLING" Y, VOLVIENDOSEA LEI FENG, DICE :- ME LO HAN DADO LOS SLPERIORES COMO
PREMIO, AHORATE LO REGALATI Y ESPERO QUE ESTLIDS VERDADERAMENTE A FONDO EL PENSAMIENTO DEL PRESIDEN TE MAO.-

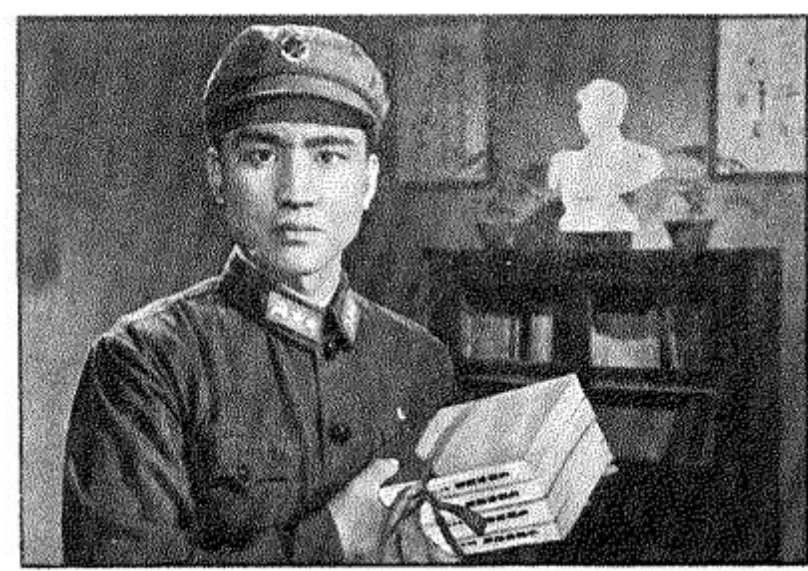

LEI FENG, YA EN SIIPODER ESTA PRECIOSA Y POTENTE ARMA REYOLLCIONARIA, LE DICE AL INSTRL CTOR SOLEMNEMENTE: - IME SERVIRA' DE HECHOS CONCRETOS PARA CORRESPONDER A VUESTRO INTERES Y A VLESTRAS ENSENANZAS?

Lei Feng (Wen Piao, 1965)

De los cinco personajes que aparecen en La bandera roja del partido vale la pena detenerse en la figura de Lei Feng. El año 2003 se conmemoró el $40^{\circ}$ aniversario de la campaña "aprendamos de Lei Feng". En las semanas anteriores al 5 de marzo los medios de comunicación chinos dedicaron una considerable atención a la cuestión de si el espíritu de Lei Feng era aún relevante y llegaron a la conclusión de que la actitud de abnegación de Lei Feng podía servir aún para promover, por ejemplo, el trabajo voluntario. Algunos portales de Internet dedicaron especiales a su vida y se publicaron ensayos educativos dedicados tanto a Feng como a las experiencias de otros 
"héroes cotidianos". En el 2006 se anunció un videojuego educativo titulado "Aprendamos de Lei Feng" en el que el jugador, tras pasar una serie de pantallas, conseguía ser recibido por el presidente Mao y recibir un autógrafo.

Lei Feng (1940-1962) fue convertido en el modelo de soldado intachable del Ejército Popular de Liberación. La infancia de Feng, que nació en el seno de una familia de campesinos pobres del distrito de Wangcheng (provincia de Hunan) el 18 de diciembre de 1940, estaba marcada por la tragedia: los japoneses habían asesinado a su padre, su madre se ahorcó por honor tras el acoso por parte del hijo de un terrateniente, su hermano mayor murió a los doce años extenuado por el trabajo y su hermano menor por el hambre. Feng vivía solo, en una cabaña semiderruida. El Partido acogió al huérfano Lei Feng, le alimentó y le proporcionó educación. Ya adulto, se unió al Ejército Popular de Liberación y al Partido Comunista. De la lectura y el estudio de las Obras escogidas de Mao en tres volúmenes que le entregó un instructor -y sobre cuya cubierta escribió las siguientes cuatro prometas: "Cada día estudiar los escritos del presidente Mao / Seguir las directrices del presidente Mao / Escuchar las palabras del presidente Mao / Ser un buen soldado del presidente Mao"- resumió que había que seguir la consigna de Mao de "construir nuestro país con laboriosidad y economía" hasta las últimas consecuencias y vivir espartanamente a la vez que dedicarse en cuerpo y alma a la revolución y al pueblo. No hay grandes hazañas en la vida de Lei Feng, sino voluntad de servir al prójimo en pequeños gestos como enviar sus ahorros a los padres de un camarada afectados por una inundación, colaborar desinteresadamente en la construcción de un edificio o lavar los calcetines, e incluso los pies, a sus camaradas tras una larga marcha. Por acciones como éstas Feng fue nombrado en 1960 "soldado economizador modelo" y puesto como ejemplo ante sus camaradas de todo el ejército chino. Lei Feng murió el 15 de agosto de 1962 a los 22 años en un accidente automovilístico, aunque hay quien duda incluso de que Lei Feng siquiera existiese y fuese más que una invención propagandística. Sea como fuere, Lei Feng se convirtió en la figura que mejor encarnaba al hombre nuevo del comunismo. Un año después de su muerte, Mao hizo un llamamiento a todo el país el 5 de marzo de 1963: «iAprended del camarada Lei Feng!» (Xiang Lei Feng tongzhi xuexi), dando el pistoletazo de salida a una campaña de propaganda que todavía hoy, como tendremos oportunidad de ver, se deja sentir. Su diario se reimprimió y se convirtió en un objeto de estudio a escala nacional y, por descontado, su vida se plasmó en todas las formas de propaganda. Lei Feng fue protagonista incluso una fotonovela donde sus acciones, al menos para un lector occidental, revestían un carácter crístico, al ser presentado casi como una encarnación del Verbo (esto es, la obra de Mao).11 De esta fotonovela, que por su precio (35 fen) era

${ }^{11}$ En efecto, Mao había escrito en 1937 que «El comunista debe ser sincero y franco, leal y
activo, poner los intereses de la revolución por encima de su propia vida y subordinar sus
intereses personales a los de la revolución. En cualquier momento y dondequiera que esté, ha
de adherirse a los principios justos y luchar infatigablemente contra todas las ideas y acciones
erróneas, a fin de consolidar la vida colectiva del Partido y su ligazón con las masas; ha de
preocuparse más por el Partido y las masas que por ningún individuo, y más por los demás que
por sí mismo. Sólo una persona así es digna de llamarse comunista.» (Mao, 1976: 285). El
novelista Rafael Chirbes ha descrito Los viejos amigos la sensación del militante ante tamaña
exigencia: «el sacrificio verdadero de la revolución no es la privación, la disciplina, ni siquiera la 
una de las más caras en su género, se imprimieron 317 mil ejemplares en una primera edición y alcanzó los dos millones de ejemplares en ediciones sucesivas. (Nebiolo, 1976: 12) De esta fotonovela escribió Umberto Eco que Feng parecía un personaje de telenovela «y, como tal, resulta insoportable (en honor a la verdad, lo es, a causa de la insistencia hagiográfica, que transforma su entrega al pueblo en una especie de masoquismo místico)» aunque, concede el semiólogo italiano, «hay que reconocer que no es, como los héroes de la literatura edificante burguesa, un portador de virtudes individuales, sino el simple vehículo ejemplar de una nueva moralidad colectiva.» (Eco, 1976: 282)

El modelo Lei Feng sirvió, en definitiva, para enseñar al pueblo chino a ser feliz ante la adversidad e incluso ante el sacrificio, a obedecer al partido y a permitir al presidente Mao que pensase por ellos. La mayor ironía de la figura de Lei Feng fue que su mejor característica era carecer de toda característica -y por encima de todo, de un pensamiento libre y crítico- y convertirse en esa "hoja de papel en blanco" que quería el presidente Mao: "La función de un hombre en los enfrentamientos de la Revolución es como la de un tornillo en una máquina. Yo seré para la Revolución un tornillo que jamás se afloja», escribió Feng en su diario. A mayor abundamiento, esta actitud promovida por Mao entraba en franca contradicción con una actitud completamente opuesta promovida por el propio Mao, quien en 1957 afirmaba que había dos maneras de aprender de los otros. "Una es -escribía- la dogmática, que consiste en copiarlo todo, sea no aplicable a las condiciones de nuestro país. Esta no es una buena actitud. La otra es hacer funcionar nuestras cabezas y aprender lo que se adapte a nuestras condiciones, es decir, asimilar cuanta experiencia nos sea útil. Esta es la actitud que debemos adoptar.» (Mao, 1976: 326-327) Pese a estas evidentes fallas internas, el modelo trató de exportarse a la Albania de Enver Hohxa durante el período de influencia china en los años sesenta. ${ }^{12}$ Después de el incidente de Tiananmen en 1989, los carteles de propaganda de Lei Feng volvieron nuevamente a la luz en un intento por restablecer la autoridad moral del partido y ofrecer, a la vez, un modelo positivo de obediencia al mismo. Recientemente, Lei Feng ha sido integrado en la cultura popular y, aunque su imagen todavía se encuentra en todas las escuelas y cuarteles militares como soldado-santo, la abnegación de Feng es tanto más extemporánea en una China en la que las ideologías de la modernidad capitalista, desde el liberalismo marcado por el "fin de las ideologías" de Daniel Bell al así llamado renacimiento neo-confuciano, ganan adeptos. (Kang, 2000: 12) Hoy su imagen acompaña desde ofertas inmobiliarias, zapatillas deportivas u oficinas bancarias, un uso que parece encajar poco con el "espíritu de tornillo" que Feng adoptó para sí mismo y propuso para los demás. Lei Feng incluso cedió por algún tiempo su nombre a una marca preservativos que se vendió en un paquete de tres al precio de 18 yuanes. Zhang Zhiwen, responsable de la marca Taotao (sita en la provincia de Zhejiang) que facturó este producto, incluso declaró -acaso con involuntario sentido del humor-que

tortura, sino el sacrificio del propio yo, dejar de ser persona, que ama sueña llora o teme, para ser máquina, motor efectivo.» (Chirbes, : 65)

12 «Se pretendía, pues, y en varios sentidos eso se logró, fabricar el hombre nuevo de acuerdo con el modelo de la literatura china que había producido el prototipo del campesino-soldado de Lei Feng, el cual lograba de manera perfecta llevar a la práctica las ideas de Mao.» (Fuga, 2002: 190). 
sus preservativos eran más fuertes que los calcetines de Lei Feng, que éste había de remendar repetidamente. Tras publicarse en la prensa internacional, la administración municipal obligó a Zhiwen a retirar el producto.13

\section{¿Después del hombre nuevo?}

El realismo socialista y el concepto de hombre nuevo entraron, como había ocurrido antes en la URSS, en un franco declive con las políticas de Deng Xiaoping en favor de representaciones más naturales y cotidianas, hasta su práctica desaparición actual con la apertura política, económica y social del socialismo de mercado chino -conocido oficialmente como "socialismo con características chinas"-. La introducción de los sucesivos paquetes de reformas trajo consigo la tercera revolución tecnológica, y con ella, la fragmentación y la diversificación de la clase trabajadora china, que poco podía identificarse ya con las viejas representaciones de obreros industriales y campesinos pobres. Así, los temas, escribe Landsberger,

«pasaron a ser menos heroicos y militantes. El estilo se hizo más impresionista y los colores brillantes se sustituyeron por tonos más sutiles. De la misma manera, los eslóganes dejaron de ser tan estridentes y militaristas para adoptar un tono más normativo: ya no se instaba al pueblo a luchar contra los enemigos - la naturaleza sino a llevar una vida con más cultura, higiene y educación. Las imágenes abstractas se impusieron al realismo: el contenido explícitamente político dio paso al entusiasmo acerca de la construcción económica o incluso la simple publicidad comercial [...] La mejora de las condiciones de vida se reflejó en una mayor diversidad en la ropa de los personajes de los pósteres, tanto en lo que respecta al material como al diseño, el corte o el color. Atrás quedaron los "trajes Mao" unisex de color azul, gris o negro que anteriormente proclamaban la condición proletaria de los chinos. El atavío revolucionario de antaño fue sustituido por zapatillas deportivas, chaquetas de piel y trajes de diseño para ellos, mientras que los pantalones cortos, los tacones de vértigo y vestidos más femeninos -incluidos los vestidos típicos de Shanghai, con sus atrevidos cortes- pasaron a ser de rigor para las mujeres. Desaparecieron el pelo al cepillo y las colas de caballo de los viejos pósteres, dando paso a las modernas permanentes y los peinados con estilo.» (Landsberger, 2003: 17)

Pregúntese el lector qué queda hoy del hombre nuevo y la respuesta que obtendrá tras un somero vistazo es: no demasiado. Ello se debe, es claro, a la extinción del campo soviético y la evolución de los regímenes supervivientes apuntada al comienzo de este artículo, por la cual esta figura ha sido fagocitada por la publicidad (el hombre nuevo como emprendedor, como capitalista dinámico), dejando espacio a nuevas expresiones de la cultura de masas que, a la vez que colman los anhelos del régimen elaborando una nueva mitología nacional patriótica y progresista, satisfacen la demanda de entretenimiento del mercado interno y externo. ${ }^{14}$ En su variante más estaliniana, sólo sobrevive, de

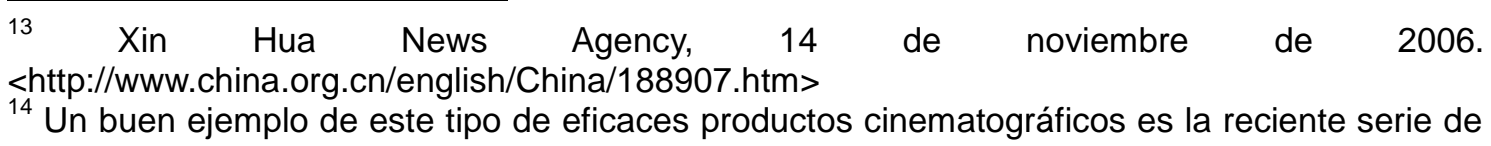


manera harto artificial como es sabido, en Corea del Norte, donde, de acuerdo con la doctrina Juche -una doctrina creada por Kim il Sung que mezcla raíces confucianas, el patriarcalismo agrario tradicional coreano y el despotismo estalinista y que se pretende superior y diferente al marxismo- y la política Songun ("el ejército primero"), el ejército asume un papel dirigente por encima incluso del Partido -algo sin precedentes en el mundo comunista- y en consecuencia es la vida castrense la que ofrece el modelo de "hombre nuevo", en la práctica una tesis mucho más cercana a concepciones reaccionarias. ${ }^{15}$

Corea del Norte ha intentado exportar este estilo y los conceptos asociados a él a algunos países africanos, como demuestra el recientemente inaugurado African Renaissance Monument en Senegal, construido por la empresa Mansudae Overseas Project, que también tiene proyectos en desarrollo en Angola y Namibia. Esta colaboración refuerza la opinión de Karl Korsch de que el marxismo no fue más que la falsa conciencia (esto es, la ideología) de la Unión Soviética y, por extensión, de todos aquellos países -en cierto modo, también China- que encontraron en el modelo soviético una rápida vía de industrialización y modernización gracias a su estructuras fuertemente centralizadas y economías planificadas. El carácter anacrónico y postizo del hombre nuevo ha dado pie a toda suerte de parodias y de reinterpretaciones irónicas en Oriente y en Occidente, desde la sátira del chino $\mathrm{Hu} \mathrm{Ge} 007$ vs. Man in Black (Hu Ge, 2007) -un mediometraje de poco presupuesto de poco más de 40 minutos, filmado en chino y en "chinglish"- ${ }^{16}$ a Kim Jong Phil, la serie de pinturas de 2011 en las que el artista Phillip Toledano se retrata sustituyendo a Kim II Sung.

Para despejar todo asomo de duda de lo que restaba del hombre nuevo, el escritor Bo Yang -que proclamó abiertamente su acracia y su independencia respecto a la República popular China y Taiwan al declarar que lo «mío no es alabar a los dirigentes, me debo sólo a la gente corriente, a los puntos de vista y a la dignidad del hombre común»- se erigió en el homólogo chino de Alexander Zinóviev con su The Ugly Chinaman and the Crisis of the Chinese Culture (1991), en la que criticaba duramente el carácter chino: «La perniciosa influencia de miles de años de gobierno feudal y autoritario -escribió- es lo que mantuvo a los chinos en la pasta de soja que bloqueó nuestro pensamiento,

películas sobre el conocido maestro de artes marciales Yip Man: Ip Man (Wilson Yip, 2008), Ip Man 2 (Wilson Yip, 2010) y The Legend is Born - Ip Man (Herman Yau, 2010). En ellas, el personaje de Ip Man, que encarna las virtudes del chino medio -a saber: modesto, bondadoso, abnegado, solidario con sus conciudadanos-, se enfrenta simbólicamente en el cuadrilátero, en escenas de combate cuidadamente coreografiadas, a los ocupantes japoneses y los colonos británicos.

${ }_{15}$ «Hwang Jang Yop, secretario del Comité Central del Partido coreano de los trabajadores, profesor de Juche de la Universidad Kim il Sung y colaborador de su hijo y sucesor, que se pasó a Corea del Sur en 1997, dice que Corea del Norte no es un país comunista porque abandonó el marxismo cuando adoptó el Juche como ideología oficial. En 1992, una frase que mencionaba el Juche como "una creativa aplicación del marxismo-leninismo" fue omitida de la Constitución. En su actual redacción (1998) la Constitución norcoreana no menciona en absoluto el término "marxismo-leninismo", o "marxismo", cita dos veces la palabra "revolución", todas dos la palabra "comunismo", cuatro veces "socialismo", seis veces "reunificación" y diez veces "Juche".» (Poch, 2009: 439)

${ }^{16}$ El neologismo "chinglish", contracción inglesa de los términos "chino" e "inglés", hace referencia al mal uso del inglés por parte de algunos chinos. 
castró nuestro juicio, pervirtió nuestra visión del mundo, y nos mantuvo aprisionados dentro de unas paredes.» (Bo Yang, 1992: 41) ${ }^{17}$ Ya en los años inmediatamente anteriores a su extinción, todos aquellos modelos y conceptos fueron objeto de una revisión irónica -paralelos al auge del posmodernismo en Occidente- ${ }^{18}$ en la Unión Sovietica por parte del llamado sots-art y en la China entrante en el socialismo de mercado por parte del llamado realismo cínico, representado por artistas como Fang Lijun, Liu Wei y Yue Minjun. De todos los artistas de esta corriente, Yue Minjun representa un caso especial. En sus obras se repite, con una insistencia que refuerza su carácter siniestro, siempre un mismo rasgo: los personajes retratados -algunos de ellos, inspirados en viejos iconos del realismo socialista- siempre ríen. Pero su sonrisa de hiena es sardónica, y lo es en ambos sentidos del término, esto es, como "convulsión y contracción de los músculos de la cara, de que resulta un gesto como cuando se ríe" y como "risa afectada y que no nace de la alegría interior". Añádase a lo dicho más arriba por Susan Buck-Morss lo escrito por Bo Yang para hacerse un retrato de la esquizofrenia del chino medio actual, atrapado entre el socialismo de estado y el turbocapitalismo: «un chino con complejo de inferioridad es un esclavo. Un chino con complejo de superioridad es un tirano. En su modalidad inferior se sienten como un montón de mierda de perro, así que cuanto más cercanos están de la gente influyente, más anchas son sus sonrisas. En su faceta arrogante, cualquier otro es un montón de mierda de perro. Estos giros radicales en su autoestima hacen de los chinos criaturas inestables de tendencias psicóticas.» Un comentarista de Bo Yang escribe que

«los chinos responden de manera uniforme, con una actitud de tolerancia resignada, a todos los tiranos, abusones y funcionarios corruptos. Ya se trate de la explotación a mano de mafias, la extorsión mediante impuestos excesivos o segando la vida de ciudadanos inocentes, los chinos responden de una manera uniforme: toleran, toleran y toleran. Esta tolerancia alcanzó cotas sin precedentes durante el reino de cierto emperador moderno (el autor se refiere a Mao, AF), cuando cualquiera que no pudiera "tolerar" era considerado un canalla. ¿Cómo afrontar el lavado de cerebro? Sonríe y aguanta. ¿Cómo afrontar ser categorizado como un burgués derechista no reformado? Sonríe y aguanta. ¿Y qué ocurre con las hambrunas? Sonríe y aguanta. Y lo mismo vale

\footnotetext{
17 Traducción de Don J. Cohn. Bo Yang apunta a los elementos conservadores del confucianismo (p. 27) -cuyo deber filial y respeto a la autoridad trocó en emasculación del pensamiento libre- y la larga historia de guerras, revueltas, corrupción, masacres y pobreza ( $p$. 50) -que generó un sentimiento inseguridad y ansiedad que los predispuso a entregarse a la burocracias en búsqueda de estabilidad-como causas probables del carácter chino. Aunque su autor jamás pretendió redactar un tratado académico (y, conviene recordarlo, se dirigía sobre todo a los propios chinos, para que, con su crítica, mejorasen), en ocasiones el texto roza el embarrado terreno de la "crítica civilizatoria". De hecho, muchas de las características que Bo Yang atribuye a los chinos -groseros, desconsiderados hacia las normas, ruidosos, fanfarrones, individualistas e incapaces de toda cooperación, etcétera- son moneda de uso corriente en las descripciones de españoles, italianos o griegos.

${ }_{18}$ «El arte postutópico ruso actual, algunos de cuyos fenómenos he descrito arriba, está, desde luego, en el cauce de lo que ahora se suele llamar posmodernismo. La aspiración a borrar las fronteras entre "lo alto" y "lo bajo" en la cultura, el interés por los mitos de la cotidianidad, el trabajo con sistemas sígnicos ya acabados, la orientación al mundo de los medios de información de masas, la renuncia a la originalidad creadora, y muchas otras cosas, emparientan la literatura y el arte rusos de los años setenta y ochenta con lo que al mismo tiempo ocurría y ocurre en Occidente.» (Boris Groys, 2008: 197).
} 
para todos los desastres naturales, los holocaustos causados por el hombre y la Revolución cultural. Sólo aquel que pueda sonreír y soportarlo puede hacer las paces consigo mismo: este es el modo tradicional chino de hacer las cosas, ¡ningún chino tiene que aprenderlo!» ${ }^{19}$

Los ecos del realismo cínico se dejan oír, entre otras, hasta la obra de Hu Ming, en la que la artista -una ex soldado del EPL que sirvió en un hospital, un tema que se repite constantemente en su obra- saca partido de los cuerpos escultóricos del realismo socialista chino y los erotiza, mezclando la estética del realismo socialista con la de las pin-ups de las revistas eróticas occidentales. Considérese, por detenernos en algún sitio, el siguiente ejemplo de Erik Bulátov proporcionado por Groys:

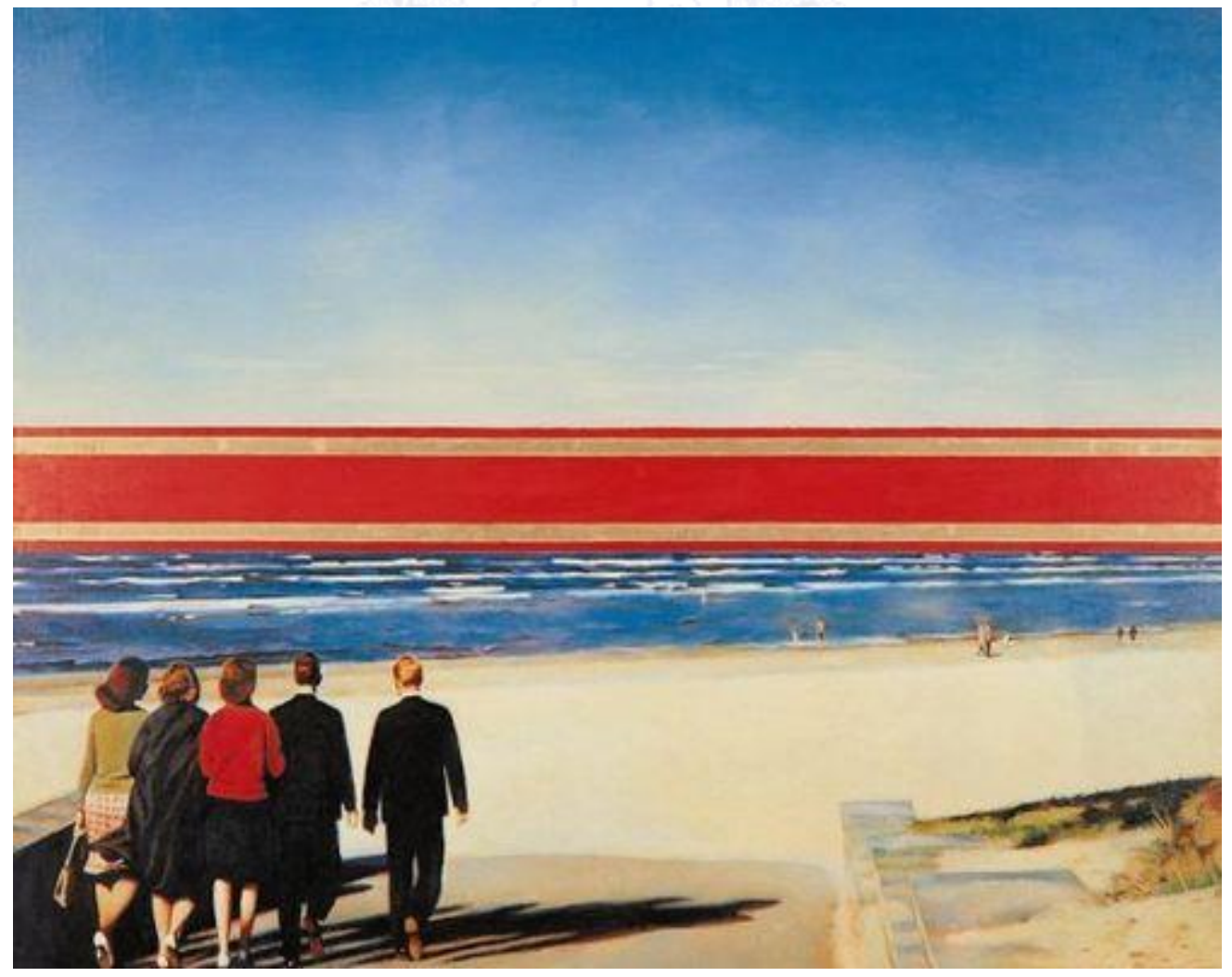

Horizonte (Erik Bulátov, 1972)

«Una de las primeras obras de ese nuevo arte postutópico que desempeñaron un papel extraordinariamente importante en el proceso de formación es el cuadro Horizonte (1972) de Érik Bulátov. En el cuadro está representado, de una manera un tanto extraña, foto-realista-socialista, un grupo de personas vestidas característicamente "a la soviética" que van por la playa, en dirección

${ }^{19}$ Bo Yang, op. cit., p. 17. De la segunda cita: Huixuan Chu, "Non-sense of humour", Hong Kong Economic Journal (Hong Kong), 23 de enero de 1985. (En Bo Yang, 1992: 130). 
el mar, al horizonte marino. Sin embargo, la línea misma del horizonte no es visible, puesto que está cubierta por una forma suprematista plana, que está como superpuesta sobre ese cuadro convencional y que lo atraviesa todo horizontalmente. Examinada más de cerca, esa forma resulta ser la cinta de la Orden Lenin.

«El movimiento hacia el mar, hacia el sol, remite al optimismo del arte realistasocialista de la época estaliniana. También los personajes están vestidos de la manera modesta y circunspecta característica de esa época, pero, a diferencia del cuadro estándar de la época estaliniana, el grupo de personas está desprovisto de espíritu festivo; está vuelto de espaldas a los espectadores, de modo que los rostros de los "hombres nuevos" no se ven; la composición esta impregnada de cierta sensación de inquietud, que surge por obra de la ejecución fotorrealista, "occidental". Es como si la cinta de la Orden, que cubre el horizonte, atajara el movimiento del grupo, lo detuviera. Al mismo tiempo, como la cinta está simplemente superpuesta sobre el cuadro, ella, en otra lectura, le señala al espectador el carácter plano y ficticio del cuadro, destruye la ilusión especial determinada por el movimiento del grupo y por la construcción trivialmente realista de la perspectiva.

«El topos del horizonte desempeña un gran papel en el pensamiento y la praxis de la vanguardia rusa. El horizonte, que se aleja a medida que uno se acerca a él, simboliza desde hace mucho tiempo el carácter engañoso de toda aspiración humana, de todo "progreso" - ese cautiverio ontológico en el que ha sido puesto el hombre en la Tierra-. El horizonte marca la frontera de las posibilidades humanas, frontera que es imposible superar precisamente porque ella misma no está quieta; con su propio movimiento cierra el paso, lo vuelve una absurda marcha en el lugar, una constante reproducción de una misma situación de partida.» (Groys, 2008: 159-160)

Con varios años de diferencia, las similitudes con la reciente obra de Weng Fen, especialmente con Sobre el muro (2002), son patentes. Esta fotografía muestra a dos colegialas que, subidas a un simbólico muro - ¿hace falta recordar lo que significa en Europa occidental?- y de espaldas al espectador, contemplan el skyline de ciudades emergentes como Cantón o Shenzhen. A un lado del muro, las miserias y el aislamiento de los países del antiguo campo socialista. Al otro, el paisaje de un capitalismo desenfrenado que tiene en sus grúas y rascacielos de vidrio reflectante -un material que, como bien supo ver Fredric Jameson en su análisis del Hotel Bonaventura, espeja la miseria del exterior e impide su visión desde el interior ${ }^{20}$ sus símbolos verticales de un poder no menos vertical. En medio, casi como el Angelus Novus de Walter Benjamin, una nueva generación que se encuentra entre las ruinas de un mundo que se derrumba y el de otro marcado por un discurso del progreso, el capitalista, que en su avance deja tras de sí un reguero de destrucción.

\footnotetext{
${ }^{20}$ Esa «fachada reflectora repele hacia afuera la ciudad; una repulsión análoga a la de esas gafas de sol especulares que hacen imposible al interlocutor ver los ojos del que habla y que, por tanto, comportan una cierta agresividad hacia el Otro y un cierto poder sobre él. De forma parecida, la fachada de vidrio produce una disociación peculiar e ilocalizable del Bonaventura con respecto a su vecindario: ni siquiera es algo exterior, ya que, cuando se intentan ver los muros externos del edificio, no se puede ver el hotel como tal, sino tan sólo las imágenes distorsionada de todo lo que le rodea.» (Jameson, 1991: 92)
} 
La aparición del realismo cínico chino y el abandono del marxismo entiéndase: lo que los dirigentes chinos entendieron bajo ese epígrafe-, no deja de ser irónico si tenemos en cuenta que China cuenta actualmente no sólo con una fuerza de trabajo como nunca antes la tuvo, sino que siendo la mayor clase obrera del mundo, es por lo general explotada en las fábricas en condiciones propias del siglo XIX, contribuyendo en buena medida en los últimos años a alterar nada menos que el equilibrio mundial entre capital y trabajo haciendo entrar los salarios en una espiral descendente. ${ }^{21}$ Cuando Mao vaticinó que la situación había llegado a un nuevo punto de viraje en el que siguiendo un proverbio chino- el viente del Este prevalecería sobre el viento del Oeste, nunca hubiera podido imaginar que se produciría bajo un signo políticoeconómico completamente opuesto al que él se imaginaba. Mientras tanto, en Europa occidental y en los Estados Unidos las antiguas representaciones del realismo socialista han sido objeto de una revalorización coleccionista. Dos casos especiales los representan los los territorios de la antigua Yugoslavia, particularmente Serbia, y los estados federados de la antigua República Democrática Alemana, donde se experimentaron, y en buena medida aún se experimenta, una nostalgia generalmente despolitizada (pero consecuencia del deterioro de la calidad de vida de los habitantes como resultado de una transición que se transformó rápidamente en un abierto latrocinio por parte de una burocracia administrativa y militar mutada en ávida élite cleptócrata) hacia los antiguos regímenes comunistas -la llamada "Yugonostalgia" en la antigua Yugoslavia y la llamada "Ostalgie" en la antigua RDA-. La desaparición del concepto de "hombre nuevo", así como de su correlato artístico, el realismo socialista -que no fue ni socialista ni realista- ha permitido, al menos, al socialismo abrirse a nuevas perspectivas democráticas, antidogmáticas y aún libertarias. Después de todo, no es el socialismo el que construye el hombre nuevo, ni, como creía Ernesto 'Che' Guevara, el hombre nuevo el que construye el socialismo, sino el hombre común.

\section{Bibliografía}

(2004) BUCK-MORSS, Susan. Mundo soñado y catástrofe. La desaparición de la utopía de masas en el Este y el Oeste. Madrid: La Balsa de la Medusa. Traducción de Ramón lbáñez Ibáñez.

(2003) CHIRBES, Rafael. Los viejos amigos. Barcelona, Anagrama.

\footnotetext{
21 «Durante la gran expansión económica china de los noventa, esta clase no conoció aumentos de salarios, ni horarios de trabajo, y sufrió gran cantidad de abusos y estafas en sus condiciones de empleo. Esta clase obrera rural fue clave para atraer la inversión extranjera a China, ocupó los talleres de la manufactura para la exportación, y los tajos y andamios de la gran urbanización y trazado de infraestructuras. Con ella, China ganó, por ejemplo, la partida contra México, en la competición por hacerse con el primer puesto en el mercado textil de Estados Unidos, pese a que México no paga aranceles en el mercado estadounidense y goza de una ventaja geográfica manifiesta.» (Poch, 2009: 96; véase asimismo cap. 5, especialmente pp. 96-104). El documental de Micha Peled China Blue (2005), sobre la vida de una joven operaria de 17 años en una fábrica de pantalones en Shaxi (provincia de Guadong) ofrece un buen retrato de las condiciones de vida de los trabajadores emigrados del campo en las fábricas de China.
} 
(2004) DOMÈNECH, Antoni. El eclipse de la fraternidad. Una revisión republicana de la tradición socialista. Barcelona: Crítica.

(1998) ENGELS, Friedrich, El origen de la familia, la propiedad privada y el estado. Barcelona: DeBarris.

(2007) FERNÁNDEZ BUEY, Francisco. Utopías e ilusiones naturales. Barcelona: El Viejo Topo.

(2002) FUGA, Artan. "El hombre nuevo"; en AA.VV. Tiran(í)a. Barcelona: Centre de Cultura Contemporània de Barcelona. Traducción de Ramón Sánchez.

(2008) GROYS, Boris. Obra de arte total Stalin. Valencia: Pre-Textos. Traducción de Desiderio Navarro.

(2004) GUBERN, Román. Patologías de la imagen. Barcelona: Anagrama.

(1991) JAMESON, Fredric. El posmodernismo o la lógica cultural del capitalismo avanzado. Barcelona: Paidós. Traducción de José Luis Pardo Torío.

(1986) JAUBERT, Alan. Le comissariat aux archives. Les photos qui falsifient I'histoire. Paris: Barrault.

(2001) LENIN, V.I. El izquierdismo, enfermedad infantil del comunismo. Barcelona: DeBarris. No consta traductor.

(1981) LUKÁCS, Georg. Gelebtes Denken. Eine Autobiographie im Dialog Frankfurt am Main: Suhrkamp. Traducción de Hans-Henning Paetzke.

(2000) KANG,Liu. Aesthetics and Marxism. Chinese Aesthetic Marxists and Their Western Contemporaries. Durham, Duke University Press.

(2007) MANCEBO ROCA, Juan Agustín. "Vanguardia y realismo socialista". En Cortés Arrese, Miguel; Mancebo Roca, Juan Agustín (eds.), El país de octubre. Murcia: Nausícaä.

(1975) MARX, Karl; ENGELS, Friedrich. Cuestiones de artes y literatura. Barcelona: Península. Traducción de Jesús López Pacheco.

(2007) MARTINSEN, Joel. "Memories vs. historical fact: Guo Wei on Dong Cunrui", Danwei.org, 16 de abril de 2007. <http://www.danwei.org/scholarship_and_education/dong_cunrui.php>

(2008) MEYERHOLD,Vsevolod. Textos teóricos. Madrid: Publicaciones de la Asociación de Directores de Escena. Traducción de J. Delgado, R. Vicente, V. Cazcarra, J.L. Bello y José Fernández.

(2003) LANDSBERGER, Stefan R. Chinese propaganda posters.Colonia: Taschen. Traducción de Lidia Álvarez Grifoll y Meritxell Tena Ripollès.

(1976) NEBIOLO, G.; CHESNAUX, J.; ECO, U. (eds.) Los cómics de Mao. Barcelona: Gustavo Gili. Traducción de Jaume Forga.

(1997) ORWELL, George. Rebelión en la granja. Barcelona, Destino. Traducción de Rafael Abella.

(2011) PISCATOR, Erwin. El teatro político. Hondarribia: Hiru, 2011. Traducción de Salvador Vilar.

(2009) POCH-DE-FELIU, Rafael. La actualidad de China. Un mundo en crisis, 
una sociedad en gestación. Barcelona: Crítica, 2009.

(2011) TROTSKY, Leo. Literatura y revolución (1924). Archivo Virtual de los Marxistas.

URL: <http://marxists.org/espanol/trotsky/1920s/literatura/indice2.htm> (Consulta: 17 de febrero de 2011).

(1976) TSÉ TUNG, Mao. El libro rojo. Citas del presidente Mao Tse-Tung. Madrid: Fundamentos. Traducción: Ediciones de Lenguas Extranjeras de Pekín. (2010) WIDMANN, Carlos. "Con secuela de sangre y muerte", Humboldt, n. 154, 2010, p. 56-58.

(1992) YANG, BO. The Ugly Chinaman and the crisis of the Chinese culture. Sydney: Allen \& Unwin. Traducción de Don J. Cohn.

(1986) ZINÓVIEV, Alexander. Homo sovieticus. Londres, Paladin, 1986. Traducción de Charles Janson. 